Вісник Дніпропетровського університету. Біологія. Екологія. -2008. - Вип. 16, т. 2. - С. 65-68. Visnyk of Dnipropetrovsk University. Biology. Ecology. - 2008. - Vol. 16, N 2. - P. 65-68.

УДК 612.017.2

\author{
I. В. Кленіна ${ }^{1}$, М. В. Горіла ${ }^{2}$, Н. І. Штеменко ${ }^{2}$ \\ ${ }^{1}$ НДІ гастроентерологіі, ${ }^{2}$ Дніпропетровський національний університет ім. Олеся Гончара,
}

\title{
ВПЛИВ ЛІПОСОМНИХ ФОРМ СПОЛУК РЕНІЮ ТА ЦИС-ПЛАТИНУ НА ТІОЛ-ДИСУЛЬФІДНЕ СПІВВІДНОШЕННЯ У КРОВІ ЩУРІВ
}

Досліджено значення тіол-дисульфідного коефіціснта у моделі in vivo, а також вивчено можливості його модифікації екзогенними чинниками. Введення ліпосомних форм комплексних сполук ренію 3 органічними лігандами призводило або до практично незмінного значення тіолдисульфідного коефіціста та не впливало на баланс тіолових та дисульфідних сполук крові тварин, що підтверджувало їх низьку токсичність, або до збільшення значення тіол-дисульфідного коефіцієта, тобто викликало підвищення реакційної здатності тіолової захисної системи організму. Показані властивості комплексних сполук ренію з органічними лігандами важливі для їх подальшого впровадження у медичну практику.

\author{
I. V. Klenina ${ }^{1}$, M. V. Gorila ${ }^{2}$, N. I. Shtemenko ${ }^{2}$ \\ ${ }^{I}$ Research Institute of Gastroenterology, ${ }^{2}$ Oles' Gonchar Dnipropetrovsk National University
}

\section{INFLUENCE OF LIPOSOME FORMS OF THE RHENIUM COMPOUNDS AND CIS-PLATIN ON THIOL-DISULFIDE COEFFICIENT IN THE RATS' BLOOD}

\begin{abstract}
Thiol-disulfide coefficient (TDC) and its different modifications in model in vivo were studied. Introduction of the liposome forms of cluster rhenium compounds with organic ligands (CROL) leads to both TDC increasing and to the constancy of the TDC. Thus, CROLs aren't toxic agents and some compounds could mobilize organisms' thiol defence system. Liposome form of cis-platin leads to the TDC decreasing. Important CROL capacities for its future medical treatment practice were shown.
\end{abstract}

\section{Вступ}

Тіол-дисульфідний коефіцієнт (ТДК) являє собою відношення кількості відновлених $S H$-груп до кількості дисульфідних (-S-S-) зв'язків. Він був запропонований для оцінки неспецифічної резистентності організму [13]. Тіолові сполуки, з яких 95 \% припадає на частку глутатіону, є однією з найважливіших систем природної резистентності клітин та організмів. Клітини, що мають дефект за функцією глутатіонсинтетази (із пониженим вмістом глутатіону), значно чутливіші до дії пошкоджуючих агентів [3; 5; 8]. Тіолові групи у ролі важливого компонента антиоксидантної системи нейтралізують активні форми кисню [12]. Буферна система, що складається з відновленого та окисненого глутатіону, поряд із системами аскорбінової кислоти та біологічно активних фенольних сполук $є$ стабілізатором оксидантно-прооксидантного гомеостазу клітин і організму [13]. Під дією токсичних речовин зміни у стані компонентів антиоксидантної системи виявляються у першу чергу. Через деякий час після інтоксикації спостерігається збільшення пулу відновленого глутатіону у печінці та нирках, що свідчить про його додатковий синтез. 
У наших роботах на моделі пухлинного росту - карциномі Герена - було розроблено нову протипухлинну систему платина - реній, що включає введення щурампухлиноносіям цис-платину (одноразово) та кластерних сполук ренію з органічними лігандами (КРОЛ) за схемою антиоксидантної терапії [15]. Однією з найважливіших складових механізму дії КРОЛ є їх значні антиоксидантні та антирадикальні властивості. Проте питання про вплив КРОЛ на систему антиоксидантного захисту інтактних та непошкоджених тканин, що $є$ обов'язковою передумовою подальшого використання комплексів, не вивчене. Мета роботи - визначити ТДК і його складові у крові щурів при введенні здоровим тваринам КРОЛ, порівняти їх вплив із впливом відомого цитостатика - цис-платину.

\section{Матеріал і методи досліджень}

Досліджували КРОЛ, що містять кластерний центр $R_{2}{ }^{6+}$, наступної будови: $\mathrm{Re}_{2}\left(\mathrm{I}-\mathrm{C}_{3} \mathrm{H}_{7} \mathrm{COO}\right)_{4} \mathrm{Cl}_{2},\left[\mathrm{Re}_{2}(\mathrm{GABA})_{2} \mathrm{Cl}_{5} \mathrm{H}_{2} \mathrm{O}\right] \mathrm{Cl} \cdot 2 \mathrm{H}_{2} \mathrm{O}, \mathrm{Re}_{2}(\mathrm{ADCOO})_{2} \mathrm{Cl}_{4}$, де $\mathrm{GABA}-\mathrm{OOC}\left(\mathrm{CH}_{2}\right)_{3} \mathrm{NH}_{3}$, $A D$ - залишок адамантану. Ліпосоми виготовляли за методом [15] та вводили у об'ємі 0,8 мл. При цьому доза препарату для сполук ренію - 7 мкмоль/кг, для цис-платину 3,5 мкмоль/кг ваги тварин.

Об'єкти дослідження - еритроцити крові щурів, яким за дві години до декапітації у хвостову вену одноразово вводили ненавантажені ліпосоми та ліпосоми, навантажені кластерними сполуками ренію з органічними лігандами або цис-платином. Як контроль використовували щурів, яким уводили фізіологічний розчин.

Для визначення співвідношення тіольних та дисульфідних зв'язків у плазмі та еритроцитах крові використано колориметричний метод з 5,5'-дитіобіс (2-нітробензойною) кислотою [4; 6]. Результати досліджень оброблялися статистично [9].

\section{Результати та їх обговорення}

Раніше показано, що введення КРОЛ із радикалами - похідними адамантанкарбонової та гамма-аміномасляної кислот у ліпосомних формах у організм тварин, що перебували у стані норми, не впливало істотним чином на стан їх системи червоної крові: не змінювало параметри еритрограм, рівень гемоглобіну, кількість ТБКактивних продуктів, активність ферментів антиоксидантного захисту [7]. Тіолдисульфідний коефіцієнт і його складові - одна з найлабільніших ділянок антиоксидантної системи організму [1]. Значення тіол-дисульфідного коефіцієнта в експериментах з уведенням ліпосомних форм КРОЛ, а також цис-платину змінювалося у досить широкому діапазоні (табл.).

Значення тіол-дисульфідного коефіціснта в еритроцитах здорових щурів $(M \pm m, n=6)$

\begin{tabular}{|l|c|}
\hline \multicolumn{1}{|c|}{ Склад ін'єкцій } & $K \frac{-S H}{-S-S-}$ \\
\hline Фізіологічний розчин (контроль) & $2,51 \pm 0,38$ \\
\hline Ненавантажені ліпосоми & $2,12 \pm 0,20$ * \\
\hline Ліпосоми, навантажені цис- $\mathrm{Pt}\left(\mathrm{NH}_{2}\right)_{2} \mathrm{Cl}_{2}$ & $0,46 \pm 0,12 *$ \\
\hline Ліпосоми, навантажені $\left[\mathrm{Re}_{2}(\mathrm{GABA})_{2} \mathrm{Cl}_{5} \mathrm{H}_{2} \mathrm{O}\right] \mathrm{Cl}_{2} \cdot 2 \mathrm{H}_{2} \mathrm{O}$ & $2,05 \pm 0,22 *$ \\
\hline Ліпосоми, навантажені $\mathrm{Re}_{2}\left(\mathrm{i}-\mathrm{C}_{3} \mathrm{H}_{7} \mathrm{COO}\right)_{4} \mathrm{Cl}_{2}$ & $3,43 \pm 0,32 *$ \\
\hline Ліпосоми, навантажені цис- $\mathrm{Re}_{2}(\mathrm{AdCOO})_{2} \mathrm{Cl}_{4}$ & $2,36 \pm 0,26^{*}$ \\
\hline
\end{tabular}

Примітка: * - дані, що вірогідно відрізняються в конторльних і експериментальних групах, $p \leq 0,05$. 
Уведення ненавантажених ліпосом не викликало значних змін ТДК, що і слід було чекати, оскільки лецитин, з якого готувалися ліпосоми, є сумішшю фосфатидилхолінів, що входять до складу мембран живої клітини.

В експериментах з уведенням цис-платину, який викликав інтенсифікацію перекисного окиснення ліпідів, тіол-дисульфідний коефіциент значно знижувався (майже у 5 разів) порівняно з нормою. Це свідчило про інтенсивне блокування цис-платином тіольних груп як у вільному, так і у зв'язаному стані. Відомо, що цис-платин блокує глутатіонову систему захисту організму [15]. Для ліпосомних форм КРОЛ з адамантановими та $G A B A$-радикалами характерне варіювання цього параметра у межах норми, що підтверджувало їх низьку токсичність. Аналогічне явище ми спостерігали в експериментах 3 еритроцитами 3 нормальною стійкістю, де не було зареєстровано значних взаємодій між клітинами та металоорганічними сполуками [7]. Ці експерименти підтверджують спостереження про переважну взаємодію ліпосомних форм КРОЛ із мембранами клітин, що мали певні пошкодження.

Застосування ліпосомних форм КРОЛ із тетраізобутиратними лігандами призводило до статистично достовірного збільшення ТДК (в 1,61 раза). Це явище можна пояснити значними антирадикальними властивостями цієї сполуки [16], показаними у експериментах in vitro зі штучно синтезованими радикалами. Здатність сполуки $\mathrm{Re}_{2}\left(\mathrm{i}-\mathrm{C}_{3} \mathrm{H}_{7} \mathrm{COO}\right)_{4} \mathrm{Cl}_{2}$ до гасіння радикала перевищувала таку у природних антиоксидантів (таких, як токоферол). Вірогідно, введення ефективної пастки для радикалів призводить до зсувів окисно-відновного стану організму, що інтенсифікує систему глутатіонового захисту. Механізм таких зсувів потребує додаткового експериментального підтвердження; він дуже важливий для застосування КРОЛ у медичній практиці.

\section{Висновок}

Введення ліпосомних форм КРОЛ призводило або до практично незмінного значення ТДК та не впливало на баланс тіолових та дисульфідних груп крові тварин (що підтверджувало їх низьку токсичність), або до збільшення значення ТДК, тобто викликало підвищення реакційної здатності тіолової захисної системи організму. Показані властивості комплексних сполук ренію з органічними лігандами важливі для їх подальшого впровадження у медичну практику.

\section{Бібліографічні посилання}

1. Барабой В. А. Содержание тиоловых групп в сыворотке крови и ткани опухоли крыс с интактным и радиорезистентным вариантами карциномы Герена // Укр. биохим. журн. 1996. - T. 68, № 1. - С. 61-65.

2. Бойцова Л. В. Вплив протипухлинних алкілуючих препаратів на стан тіолової системи // Ліки. - 1996. - № 4. - С. 96-103.

3. Бойцова Л. В. Захисна роль глутатіонової системи в органах пацюків при введенні ембіхіну // Укр. біохім. журн. - 1998. - Т. 70, № 1. - С. 113-117.

4. Веревкина И. В. Колориметрический метод определения $S H$-групп и $S S$-связей в белках при помощи 5,5-дитиобис(2-нитробензойной) кислоты / И. В. Веревкина, А. И. Точилкин, Н. А. Попова // Современные методы в биохимии. - 1977. - Т. 5, № 3. - С. 223-231.

5. Воскресенский О. Н. Вільно-радикальне окислювання, антиоксиданти й атеросклероз // Кардіологія. - 1981. - № 6. - С. 118-123.

6. Горячковский А. М. Справочное пособие по клинической биохимии. - Одесса, 1994. - 298 с.

7. Зеленюк М. А. Біологічна активність ліпосомних форм комплексних сполук ренію (III) 3 органічними лігандами: Автореф. дис. ... канд. біол. наук: 03.04.03 /ХНУ. - М., 2005. - 32 с. 
8. Кулинський В. І. Біологічна роль глутатіону / В. І. Кулинський, Л. С. Колесниченко // Успіхи сучасної біол. - 1990. - Т. 110, № 1 (4). - С. 20-33.

9. Лакин Б. Ф. Биометрия. - М.: Наука, 1990. - 280 с.

10. Олійник С. А. Токсикологія сполук ренію: погляд на проблему / С. А. Олійник, Н. І. Штеменко, Н. О. Горчакова // Современные проблемы токсикологии. - 2001. - № 1. - С. 3-12.

11. Олійник С. А. Антирадикальна активність комплексів ренію 3 органічними лігандами / С. А. Олійник, Н. І. Штеменко, А. В. Штеменко // Доповіді НАНУ. - 2001. - № 7. - С. 176-180.

12. Печінкова енцефалопатія: простий або складний діагноз / В. Т. Івашкін, М. В. Маєвська, Ч. С. Павлов та ін. // Рос. журн. гастроентерол., гепатол., колонопроктол. - 2000. - Т. 10, № 5, Прил. 11. - С. 80-84.

13. Соколовський В. В. Тіол-дисульфідне співвідношення крові як показник стану неспецифічної резистентності організму: Навчальний посібник. - С-Пб-М.,1996. - 33 с.

14. Shtemenko A. V. Chemistry of binuclear Rhenium clusters / A. V. Shtemenko, B. A. Bovykin // Rhenium and Rhenium Alloys. - Pensilvania: TMS publication, 1997. - P. 189-197.

15. Shtemenko N. I. Dichlorotetra- $\mu$-isobutiratodirhenium(III): enhancement of cisplatin action and KBC-stabilizing properties / N. I. Shtemenko, P. Collery, A. V. Shtemenko // Anticancer Research. - 2007. - Vol. 27. - P. 2487-2492.

Надійшла до редколегії 11.12.2007 